IFN Working Paper No. 714, 2007

\title{
Parallel Development? Productivity Growth Following Electrification and the ICT Revolution
}

Harald Edquist 


\title{
Parallel Development? Productivity Growth Following Electrification and the ICT Revolution ${ }^{*}$
}

\author{
Harald Edquist \\ Swedish Centre for Business and Policy Studies \\ and \\ Research Institute of Industrial Economics \\ Box 5629 \\ S 11486 Stockholm \\ SWEDEN \\ Phone: +46-8-507 02559 \\ Fax: +46-8-507 02545 \\ E-mail: Harald.Edquist@sns.se
}

\begin{abstract}
This paper investigates labor productivity growth and the contribution to labor productivity growth in Swedish manufacturing during electrification and the ICT revolution. The paper distinguishes between technology-producing, intensive and less intensive technology-using industries during these technological breakthroughs. The results show that labor productivity growth and the overall contribution to labor productivity growth was considerably higher in technology-producing industries following the ICT revolution. Moreover, the results presented here show no evidence that industries that were early adopters of electric motors and ICT, on average would have contributed more to productivity growth in Swedish manufacturing.
\end{abstract}

JEL Classification: N64, O33, O47

Keywords: Electrification, ICT revolution, Productivity growth, Technological change

\footnotetext{
* I am grateful for useful comments and suggestions from Magnus Henrekson, Rolf Henriksson, Håkan Lindgren and Daniel Waldenström and participants at seminars at the Stockholm School of Economics. Financial support from Jan Wallander's and Tom Hedelius' Research Foundation is also gratefully acknowledged.
} 


\section{Table of contents}

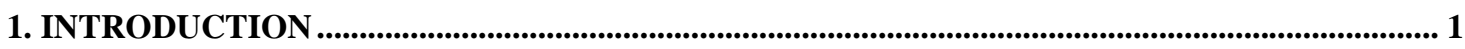

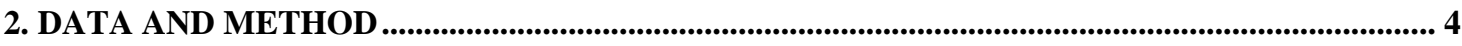

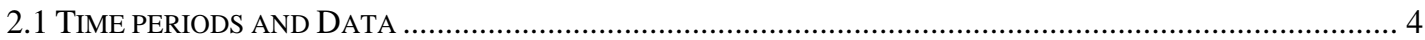

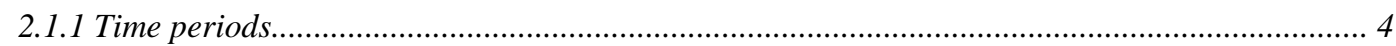

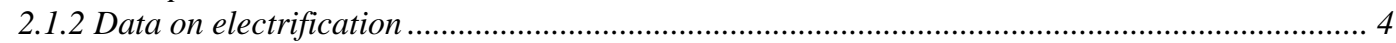

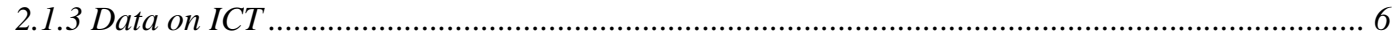

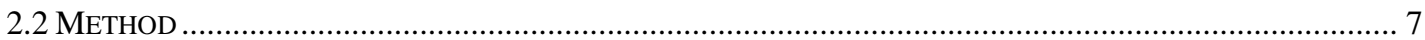

2.2.1 Classification of technology intensive industries ................................................................ 7

2.2.2 Problems with measuring power in manufacturing ..................................................................10

2.2.3 Industry contribution to aggregate productivity growth ...........................................................10

3. DIFFUSION OF ELECTRIC MOTORS AND ICT IN MANUFACTURING ...................................13

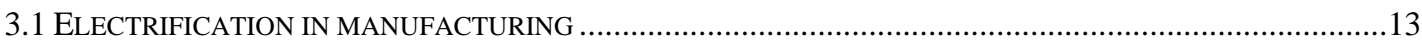

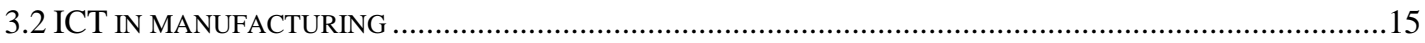

3.3 DEFINING INDUSTRIES THAT WERE INTENSIVE USERS OF NEW TECHNOLOGY .................................17

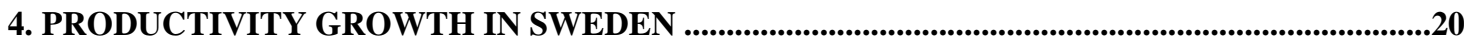

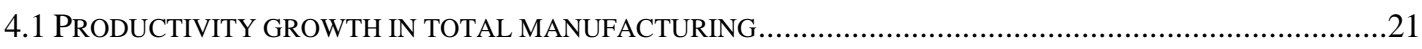

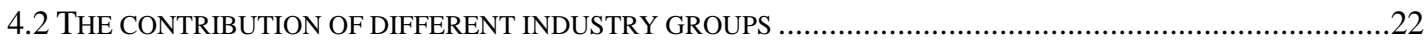

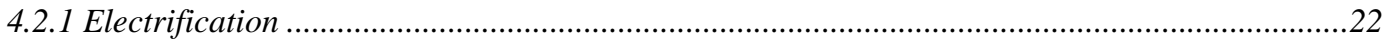

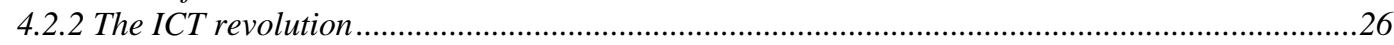

4.3 COMPARING ELECTRIFICATION AND THE ICT REVOLUTION ........................................................28

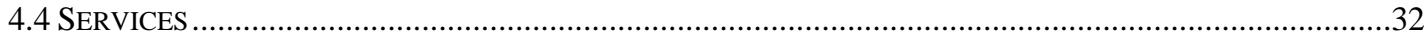

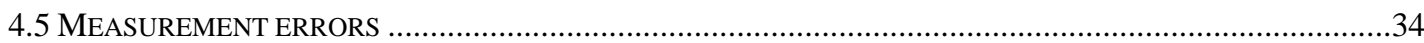

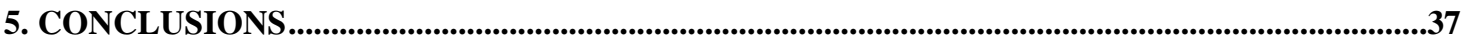

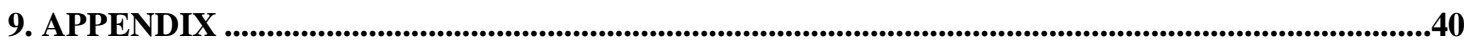

APPENDIX A: THE REVISION OF SWEDISH INDUSTRY CLASSIFICATION IN 1913.......................................40

APPENDIX B: ESTIMATION OF LABOR COMPENSATION …...........................................................41

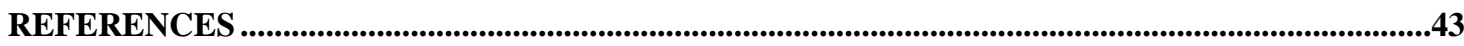




\section{Introduction}

Since the eve of the industrial revolution, there have been a number of major technological breakthroughs. Steam, electricity, internal combustion and information and communication technology (ICT) are only a few examples. One way of distinguishing revolutionary technologies from less important technologies is to use the General Purpose Technology (GPT) concept. According to the GPT framework, whole eras of technical progress are driven by a few GPTs, characterized by pervasiveness, inherent potential for technical improvements and innovational complementarities giving rise to increasing returns to scale (Bresnahan \& Trajtenberg 1995). ${ }^{1}$ A number of studies have compared the impacts of different GPTs (see, for example, David 1990; 1991; Gordon 2000; Crafts 2004(a,b); Jovanovic \& Rousseau 2005; Edquist \& Henrekson 2006; van Ark \& Smits 2007). Most of these studies have focused on the development in the British or US economy. This paper will compare two GPTs in Sweden, namely electrification and the information and communication technology (ICT) revolution.

Even though electrification and the ICT-revolution can be classified as GPTs, there are also differences between the two technologies. For example, electricity is essentially dependent on a fixed grid and a centralized provision structure while ICT is based on a network and decentralized production structure. Moreover, without electrification there would never have been any ICT-revolution since ICT is totally dependent on access to electricity. This paper investigates if there also are important differences in how the two GPTs affected productivity growth.

Several studies have argued that the increased use of electric motors in manufacturing had an important, but delayed effect on productivity growth (Devine 1983; David 1990; 1991). The impact of ICT on productivity growth has been debated over the last decades. For a long time, there was little evidence that the use of computers and other ICT

\footnotetext{
${ }^{1}$ There are also other theoretical approaches for analyzing major technological breakthroughs; see, for example, Freeman \& Soete (1987).
} 
equipment had any significant impact on productivity growth. ${ }^{2}$ However, since the post 1995 increase in productivity growth in the US economy, there is evidence of increased use of ICT having had positive effects on productivity growth. Several firm-level studies suggest ICT use to have a large economic impact (Brynjolfsson \& Hitt 2000). Moreover, a number of growth accounting studies have shown that the spectacular productivity growth in the US starting in the mid 1990s occurred with the widespread diffusion of ICT in the economy (Oliner and Sicher 2000; Jorgenson and Stiroh 2000). Nonetheless, there are also studies that are more skeptical towards the economic impact of ICT across industries. Gordon (2000) argues that the revival in productivity growth primarily occurred within durable goods production, particularly in ICT-producing industries. He suggests that the effects of ICT have not been far reaching, but rather concentrated to a few industries of the economy.

A new perspective of the impact of ICT has been to investigate the impact on productivity growth by ICT-producing, intensive ICT-using and less intensive ICT-using industries. ${ }^{3}$ According to Stiroh (2002), industries that made the largest ICT investments in the 1980s and early 1990s have had larger productivity gains after 1995. Stiroh also provides a decomposition of aggregate productivity growth into the contribution of individual industries. The results show that ICT-producing and ICT-intensive using industries accounted for approximately 80 percent of productivity growth in the US economy 1995-2000. Moreover, these industries also accounted for all the direct industry contributions to the US acceleration in productivity growth in 1995-2000, as compared to 1987-1995. A similar framework is used by van Ark et al. (2003) to show that the key differences in productivity growth between Europe and the US are in intensive ICT-using services.

The findings by Stiroh (2002) and van Ark et al. (2003) raise questions about how important technology-producing, intensive and less intensive technology-using industries

\footnotetext{
2 This paradox has been named the Solow Paradox after Nobel Laureate Robert Solow’s statement: "You can see the computer age everywhere but in the productivity statistics" (Solow 1987, p. 36).

${ }^{3}$ These industries are defined according to Stiroh (2002) and van Ark et al. (2003) and discussed in section 2.2.1.
} 
were for earlier GPTs. By comparing the impacts of electrification and ICT in the US, Jovanovic \& Rousseau (2005) find that electrification was more broadly adopted, while ICT seems to be more technologically revolutionary. However, Jovanovic and Rousseau do not investigate the impact of industries using the new technology more intensely during the two breakthroughs. To my knowledge, no one has investigated the contribution of intensive technology-using industries to labor productivity growth following earlier technological breakthroughs. The primary purpose of this paper is therefore to use the framework provided by Stiroh (2002) and van Ark et al. (2003) to compare the contribution to labor productivity growth by technology-producing, intensive and less intensive technology-using industries following two GPTs, namely electrification and ICT. The object of study is Swedish manufacturing.

The paper consists of two parts. The first part provides a short overview of electrification and the ICT revolution in Sweden. In particular, the diffusion of new technology in manufacturing will be emphasized. The second part uses decomposition methods to investigate the contribution of technology-producing, intensive and less intensive technology-using industries on labor productivity growth during electrification and the ICT revolution. More specifically, the following questions will be addressed:

- How long did it take until the new technology was adopted in Swedish manufacturing during each breakthrough?

- When did labor productivity start to increase in Swedish manufacturing following the introduction of the new GPTs?

- How much did manufacturing industries classified as producers, intensive and less intensive users of the new technology contribute to labor productivity growth following electrification and the ICT revolution in Swedish manufacturing? ${ }^{4}$

\footnotetext{
${ }^{4}$ This article does not investigate whether investments in new technology actually resulted in higher productivity growth. Instead, a comparative perspective is used to investigate whether there is a major difference in productivity growth patterns in technology-producing, intensive and less intensive technology-using industries following electrification and the ICT revolution.
} 
To answer these questions, data have been collected from a number of different sources. Section 2 describes the data and methods used. Section 3 provides a short overview of the diffusion of new technology during electrification and the ICT revolution. Section 4 investigates the contribution to labor productivity growth from technology-producing, intensive and less intensive technology-using industries. Section 5 concludes.

\section{Data and method}

\subsection{Time periods and Data}

\subsubsection{Time periods}

According to Gordon (2006) the 1920s and 1990s featured an explosion of applications of a fundamental "General Purpose Technology" in the US. Moreover, both decades experienced productivity growth acceleration and the accompanying booms of investments. The investigation of electrification in Sweden will focus on the contribution to labor productivity growth in the interwar period 1920-39. The reason for this is to avoid the effects of World Wars I and II on the Swedish economy. The period 1920-39 will be divided into subperiods 1920-30 and 1930-39, which implies that productivity is measured from peak-to-peak over the business cycle. ${ }^{5}$ According to Field (2003), choosing business cycle peaks for beginning and end points largely controls for the variations in capacity utilization that occur over the business cycle. ${ }^{6}$ The productivity analysis for the ICT revolution will be carried out for the period 1993-2004. According to Statistics Sweden (2005), 1993 was at the bottom of the Swedish business cycle and 2004 is the last year with available data.

\subsubsection{Data on electrification}

The data that are used to analyze electrification in Swedish manufacturing are based on primary data collected from the Swedish Official Statistics (Kommerskollegium 1906-

\footnotetext{
${ }^{5}$ According to Edvinsson (2005), 1920, 1930 and 1939 were years when the business cycle peaked in Sweden.

${ }^{6}$ The period 1920-30 was characterized by an investment boom, while there was an economic downturn in the early 1930s in Sweden. Nonetheless, the Swedish employment growth was positive during the two periods $1920-30$ and $1930-39$.
} 
1939) and the Swedish Statistical Yearbook (1922-42). The data include figures of primary power capacity in Swedish manufacturing at a very detailed industry level. ${ }^{7}$

In addition to primary power, the data also include the total capacity of electric motors used in manufacturing and the capacity of "driving generators", i.e. prime movers involved in generating electricity. ${ }^{8}$ This makes it possible to distinguish between the primary capacity used for direct drive and the primary capacity used to produce electricity. ${ }^{9}$ By dividing the capacity of electric motors by the sum of the capacity of prime movers used for direct drive and electric motors, a measure of the capacity of electric motors used in total mechanical drive is obtained. This measure provides a very good indication of the intensity of electric motors used in each industry. ${ }^{10}$

The Swedish Official Statistics started to report the capacity of electric motors used in manufacturing in $1906 .{ }^{11}$ In 1913, a major revision of the Swedish industry classification system was implemented. One major change in the classification of 1913 was the exclusion of firms with less than ten employees (see appendix A). This implies that the aggregate figures for the period 1906-1912 are not fully comparable with the figures for the period 1913-1939. Therefore, data for the period 1906-1939 will only be used to describe the process of electrification for aggregate manufacturing. ${ }^{12}$

Productivity estimates for manufacturing during electrification are based on data of production value and the number of persons employed provided by Kommerskollegium

\footnotetext{
${ }^{7}$ Primary power is the power produced by prime movers that utilize the potential energy of nature and directly convert it into energy of motion (Du Boff 1979).

${ }^{8}$ In this paper, power capacity is measured in horsepower, where one unit is equivalent to a rate of 550 foot-pounds per second.

${ }^{9}$ Those machines run directly by installed prime movers are said to be powered by direct drive.

${ }^{10}$ This measure of electric motor intensity cannot be used for the US economy before 1939. The reason is that there are no estimates of driving generators available for this period (Du Boff 1979). The US data distinguish between primary electric motors and secondary electric motors. Primary electric motors are driven by electricity purchased from utilities outside the manufacturing plant, secondary electric motors are driven by electricity from generators and prime movers within the plant itself. However, the relationship between secondary electric motors and driving generator is difficult to establish and can vary between different industries (Du Boff 1979).

${ }^{11}$ The capacity of electric motors was also reported in 1896, but not for the period 1896-1905.

${ }^{12}$ The choice of 1939 as the end year for the investigation is due to the outbreak of World War II and the fact that approximately 90 percent of Swedish manufacturing had been electrified by then.
} 
(1920-1939). Price indexes and industry classification are based on Ljungberg (1990). ${ }^{13}$ The industry classification includes 32 industries - see table $2 .{ }^{14}$ Mining and Power lightning and waterworks are not considered to belong to manufacturing and are therefore excluded. ${ }^{15}$ Unfortunately it has not been possible to obtain satisfactory data on capital inputs at the detailed industry level. Thus, it has not been possible to provide estimates of total factor productivity (TFP). Nonetheless, it can be argued that labor productivity is the appropriate measure. According to Stiroh (2002) the primary effect of the use of new technology is likely through traditional capital deepening channels. Hence, in this view ICT is not a special type of capital, but rather a normal piece of equipment that firms invest to raise profits. Thus, in this neoclassical world, TFP gains should only be seen in the production of ICT, where true technological progress allows the production of improved capital goods at lower prices (Stiroh 2002). It is though important to be aware that spillover effects, i.e. TFP growth in sectors using the new technology, and capital deepening are not directly separated due to data constraints. ${ }^{16}$

The method used to calculate the contribution of each industry to labor productivity growth requires data on labor compensation (see section 2.2.3). Labor compensation during electrification has been estimated using data on wages and the number of persons employed at the industry level. These data are based on the Swedish Statistical Yearbook (1922-42) and Kommerskollegium (1920-39). For a detailed description of the sources and underlying assumptions used to estimate labor compensation, see appendix B.

\subsubsection{Data on ICT}

It has been more difficult to find data on the diffusion of ICT than on the diffusion of electric motors. One reason for this is that Statistics Sweden did not conduct any major surveys of the diffusion of ICT in Swedish manufacturing until 2000. The only data

\footnotetext{
${ }^{13}$ The data for production value and electric motor capacity were available at even less aggregated industry levels, but production value in fixed prices could not be estimated for these industry levels.

${ }^{14}$ There were no price indexes available for Furniture and fixtures and Converted paper products. Hence, it has not been possible to estimate productivity for these industries and therefore, they have been excluded in table 2.

${ }^{15}$ These industries are excluded because they are not included in manufacturing in 1993-2004.

${ }^{16}$ According to Jalava \& Pohjola (2005) TFP is likely to increase at a later stage after the introduction of new technology.
} 
available are the ICT capital stock. However, they are only available at a very aggregate level (see section 3.2). Thus, there is a lack of ICT technology data in Swedish manufacturing in 1980-1999. However, for the period 2000-2004, it has been possible to find data on ICT diffusion in manufacturing. These data are based on surveys that Statistics Sweden started to conduct in 2000.

Data on labor productivity during the ICT revolution are based on the EU KLEMS database (KLEMS 2007), which include figures on value added, production value, persons engaged and labor compensation in 1993-2004. The database includes figures of both manufacturing and services. One major problem with comparing the productivity development during electrification and the ICT revolution is that there are no productivity estimates available for the service sector during electrification. Moreover, the productivity estimates for services are also very uncertain for the ICT revolution due to measurement problems. Therefore, services will only be included to show that the main results of the productivity development during the ICT revolution are robust also when service industries are included (see section 4.3).

\subsection{Method}

\subsubsection{Classification of technology intensive industries}

To distinguish between industries that were using electric motors more or less intensely during electrification, a similar method as that proposed by Stiroh (2002) and van Ark et al. (2003) will be used. Stiroh uses the flow of capital services from ICT as a share of total capital services. ${ }^{17}$ Then, he defines the ICT-intensive industries as the industries with an above median value of the 1995 ICT share of capital services. The industries with below median value are defined as less intensive ICT-using industries. The definition of ICT-producing industries is based on OECD (2002). According to OECD (2002) a

\footnotetext{
${ }^{17}$ Capital services are the flow of services from the stock of capital. The flows of the quantity of capital services are not usually directly observable and therefore must be approximated by assuming service flows to be in proportion to the stock of assets after each vintage has been converted into standard efficiency units. This is done using age efficiency units because older assets are usually less efficient than newer ones (see OECD 2001).
} 
manufacturing industry is classified as ICT-producing if it is intended to fulfill the function of information processing and communication, including transmission and display; or use electronic processing to detect measure and/or record physical phenomena, or to control a physical process. ${ }^{18}$

There are no estimations of the flow of capital services available during electrification in Sweden. Therefore, the industries with an above median value of the electric motor capacity as a share of total mechanical drive capacity will be defined as intensive users of electric motors. Thus, the measure is a proxy for how much of the total machinery stock that had been electrified at a specific time period. According to David (1990) it was first when approximately 50 percent of the mechanical drive capacity had been electrified that productivity started to increase. In the US diffusion reached this level in the 1920s, however in Sweden the 50 percent level of diffusion was reached already in 1914-15. Thus, diffusion of electricity in Sweden was more rapid than in the US. Therefore, the average ratio of electric motors and total capacity in mechanical drive in 1914-15 will be used to define which industries that were electric motor intensive. Moreover, the only industry producing electric equipment was Electric machinery and cables. Therefore, it will be defined as the electric motor equipment producing industry.

There are also other possible measures that could be used to measure the intensity of electric motors used in production. It could be argued that electric motors saved energy and that it was therefore possible to increase the power capacity per employee. Hence, electric motor capacity per employee could be another way of measuring electric motor intensity. Why then is electric motor capacity as a share of total mechanical drive capacity to be preferred to other measures? According to David (1991) and Devine

\footnotetext{
${ }^{18}$ OECD (2002) defines the following manufacturing industries as ICT-producing: Office accounting and computing machinery (ISIC 30), Insulated wire and cable (ISIC 313), Radio, television and communication equipment (ISIC 32), Instruments and appliances for measuring, checking, testing, navigating and other purposes, except industrial process control equipment (ISIC 3312). Industrial process control equipment (ISIC 3313). Since there are no data available for ISIC 3312 and 3313 in the EU KLEMS database, the more aggregated industry scientific instruments (ISIC 331-3) will be used to define the ICT-producing industries (see table 3). Moreover production value was not available for ISIC 331 and ISIC 313. Therefore, value added growth rates and shares were used to calculate the contribution to labor productivity for these industries.
} 
(1983), the most important reasons why the introduction of electric motors resulted in productivity gains were:

- Reduced labor requirements for oiling and maintaining the old drive apparatus.

- Better utilization of labor and materials through rationalization, which was made possible due to the greater flexibility of factory lay-outs when the latter were freed from the constraints formerly imposed by the requirement of orthogonal placement of drive-shafts and machinery.

- Improved machine control leading to increases in output and quality, which was achieved by eliminating the problems of belt slippage.

- Savings in fixed capital through lighter factory constructions.

- Decreased losses since the entire power system did not have to be shut down to carry out maintenance and replacement of some of the machinery.

According to David (1991) and Devine (1983), productivity started to increase primarily because the old machinery was replaced by electric motors. Thus, it was not that each worker got access to more power capacity, but rather the flexibility of electric motors that resulted in increased productivity growth. Therefore, it is necessary to use a measure taking into account how far the replacement process of old equipment had proceeded within different industries to define electric motor intensity.

It is always difficult to establish an exact breaking point for which industries should be classified as intensive electric motor using industries. Therefore, the method favored by Stiroh (2002) will be used, i.e. industries with an above median value of the electric motor capacity as a share of total mechanical drive capacity. This implies that some industries will be classified in different industry groups, even though the difference in electric motor intensity between them is very small (see section 3.3). Daveri (2004) criticizes this arbitrary cut-off point arguing that stricter cut-off points would provide different results. However, since the purpose of this paper is rather to compare the relative importance of intensive and less intensive technology-using industries the cut-off point is valid as long as it is the same for both GPTs. 


\subsubsection{Problems with measuring power in manufacturing}

Section 2.1.2 explained how power capacity would be used to describe the process of electrification in Swedish manufacturing and define which industries were intensive users of electric motors. Nevertheless, there is one major problem with using capacity data to analyze electrification. Horsepower capacity does not necessarily reflect the work output, i.e. the amount of useful work actually done by a prime mover or electric motor.

It is likely that the full capacity of electric motors or other prime movers was never utilized. Moreover, the rates of capacity utilization vary between different power sources. According to Du Boff (1979), the capacity utilization of electric motors was lower as compared to steam engines. The decentralization process following electrification meant that a few steam engines would be replaced by tens or hundreds of electric motors, each powering an individual machine. It is likely that the combined power capacity of these motors would be greater than the steam power they replaced. Hence, capacity would increase, while the horsepower work output would remain the same. However, estimates by Du Boff (1979) show that these effects were decreasing as the utilization of electric motors increased over time, due to better organization of the production process.

It is important to be aware of the caveats associated with the use of power capacity to analyze electrification. Still, since there are no data available on work output during electrification, data on power capacity remain the best estimates available to analyze the electrification process over time.

\subsubsection{Industry contribution to aggregate productivity growth}

There are a number of different methods available for measuring the contribution of each industry to aggregate productivity growth (see Domar (1961), van Ark et al. 2003; Stiroh 2002; OECD 2001). Here, the method recommended by OECD (2001) is used. ${ }^{19}$

\footnotetext{
${ }^{19}$ The reason for using the method recommended by the OECD (2001) is that it has been possible to obtain the required data for this method. The method used by Stiroh (2002) requires data on intermediate inputs which are not available in 1920-39. Moreover, the method recommended by Domar (1961) are primarily used when total factor productivity is aggregated.
} 
Labor productivity, $L P$ for industry $i$ is given by the relation:

$\frac{d \ln L P_{i}}{d t}=\frac{d \ln V A_{i}}{d t}-\frac{d \ln L_{i}}{d t}$,

where $V \hat{A}_{i}$ is the rate of change of real value added in industry $i$ and $\hat{L}_{i}$ is the rate of change of labor input.

The aggregate rate of change in value added is a share of the weighted average of the industry-specific rate of change of value added, where weights reflect the current price share of each industry in output (OECD 2001). Thus, if $n$ is the total number of industries:

$\frac{d \ln V A}{d t}=\sum_{i=1}^{n} s_{i}^{V A} \frac{d \ln V A_{i}}{d t}, \quad$ where $s_{i}^{V A}=\frac{P_{i}^{V A} V A_{i}}{P^{V A} V A}$ and $P^{V A} V A=\sum_{i=1}^{n} P_{i}^{V A} V A_{i}$,

where $P_{i}^{V A} V A_{i}$ denotes the current price (index) of value added for industry $i$, composed of a price index $P_{i}^{V A}$ and a quantity index $V A_{i}$.

The aggregation of industry-level labor input is achieved by weighting the growth rates of labor input by industry with each industry's share in total labor compensation. ${ }^{20}$

$\frac{d \ln L}{d t}=\sum_{i=1}^{n} s_{i}^{L} \frac{d \ln L_{i}}{d t}, \quad$ where $s_{i}^{L}=\frac{w_{i} L_{i}}{w L}$ and $w L=\sum_{i=1}^{n} w_{i} L_{i}$

where $w_{i}$ is labor compensation in industry $i$.

It then follows that aggregate labor productivity growth is defined as the difference between aggregate growth in value added and aggregate growth in labor input,

${ }^{20}$ The estimation of labor input in 1920-39 is described in appendix B. 
$\frac{d \ln L P}{d t}=\sum_{i=1}^{n}\left(s_{i}^{V A} \frac{d \ln V A_{i}}{d t}-s_{i}^{L} \frac{d \ln L_{i}}{d t}\right)$.

Thereby, the contribution of industry $i$ to aggregate labor productivity growth is $s_{i}^{V A} \frac{d \ln V A_{i}}{d t}-s_{i}^{L} \frac{d \ln L_{i}}{d t}$ or the difference between its contribution to total value added and total labor input. Another way of representing equation (4) is by decomposing it into a weighted average of industry-specific productivity growth and a reallocation term $R$

$\frac{d \ln L P}{d t}=\sum_{i=1}^{n} s_{i}^{V A}\left(\frac{d \ln V A_{i}}{d t}-\frac{d \ln L_{i}}{d t}\right)+R$ where $R=\sum_{i=1}^{n}\left(s_{i}^{V A}-s_{i}^{L}\right) \frac{d \ln L_{i}}{d t}$.

The reallocation term $R$ will be positive if an expanding industry (i.e. an industry with an increase in labor input) holds a share in output exceeding its share in labor compensation. This implies that this industry has a higher than average level of labor productivity. A shift of resources to industries with higher levels of productivity implies an increase in aggregate productivity growth (OECD 2001). However, if an expanding industry holds a share in labor compensation exceeding its share in output, the industry has a lower than average level of labor productivity and the shift of resources will then imply a decrease in aggregate productivity growth. ${ }^{21}$

There are no value added data available at the most detailed industry level for the period 1920-39. Therefore, labor productivity estimates during electrification will be based on production value. The use of production value at the industry level implies problems of double counting of intermediary inputs. This means that production value does not only include final output, but double counts those intermediate inputs produced within the industry that are used internally.

\footnotetext{
${ }^{21}$ It is possible that productivity in manufacturing increases because firms with lower than average productivity growth are shut down. If the released employees are then not used in production processes with higher productivity growth, the growth rate of GDP per capita in the total economy will decrease, even though productivity growth in manufacturing increases.
} 
As pointed out by Bailey (1986), this problem is very large at the aggregate level, but decreases at the disaggregated industry level. Hence, Bailey (1986) argues that to analyze productivity within manufacturing, it is possible to use either production value or value added. Moreover, to avoid double counting as far as possible, only production value based on the sales values of the final products was used to estimate productivity growth. To make the comparison of productivity growth following the two technological breakthroughs as accurate as possible, production value will also be used to estimate productivity growth following the ICT revolution.

\section{Diffusion of electric motors and ICT in manufacturing}

\subsection{Electrification in manufacturing}

Electricity and electric motors were first introduced in Swedish manufacturing during the 1880s. The first users of electricity were the industrial sector and urban households (Kander 2002). In manufacturing, electricity was first used to illuminate factories. But, as the performance of electric motors was improved, they were increasingly used in the manufacturing process (Schön 1990; Norgren 1992). The first electric motors were constructed for direct current. However, as the advantages of transmitting electricity, in the form of alternating current, became evident in the 1890s, the alternating current electric motor came to dominate the market. ${ }^{22}$

In 1896, the capacity of electric motors as a share of total mechanical drive was 2.7 percent. ${ }^{23}$ Figure 1 shows the capacity of electric motors, steam power, water power and gas and petrol engines as a share of the total capacity used for mechanical drive in 19061939. According to figure 1 , the share of electric motor capacity used for mechanical

\footnotetext{
22 The first transmission of electricity in Sweden over a longer distance was carried out between Hellsjön and Grängesberg in 1893 (Hjulström 1940). Nonetheless, it took a long time until more than 50 percent of the mechanical drive had been electrified in Swedish manufacturing.

${ }^{23}$ The first statistics of the capacity of electric motors is from 1896. For the period 1897-1905, the capacity of electric motors was not reported in the official statistics. This implies that consistent figures are only available for the period 1906-1939.
} 
drive increased steadily over time. In 1906, 18.6 percent of the mechanical drive in Swedish manufacturing was performed by electric motors, while the corresponding figure in 1939 was 88.9 percent. Hence, Swedish manufacturing was electrified very rapidly in the early twentieth century. According to Devine (1983), the first electric motors used in production just replaced steam engines and water wheels. A further step was to connect a single electric motor to each machine. This unit drive system resulted in increased flexibility of the production process. According to Schön (1990), the unit drive system was implemented in most Swedish factories in the 1920s.

Figure 1: $\quad$ Capacity of electric motors, water power, steam power and petrol and gas engines as a share of the total capacity of the mechanical drive in Swedish manufacturing 1906-1939 (percent)

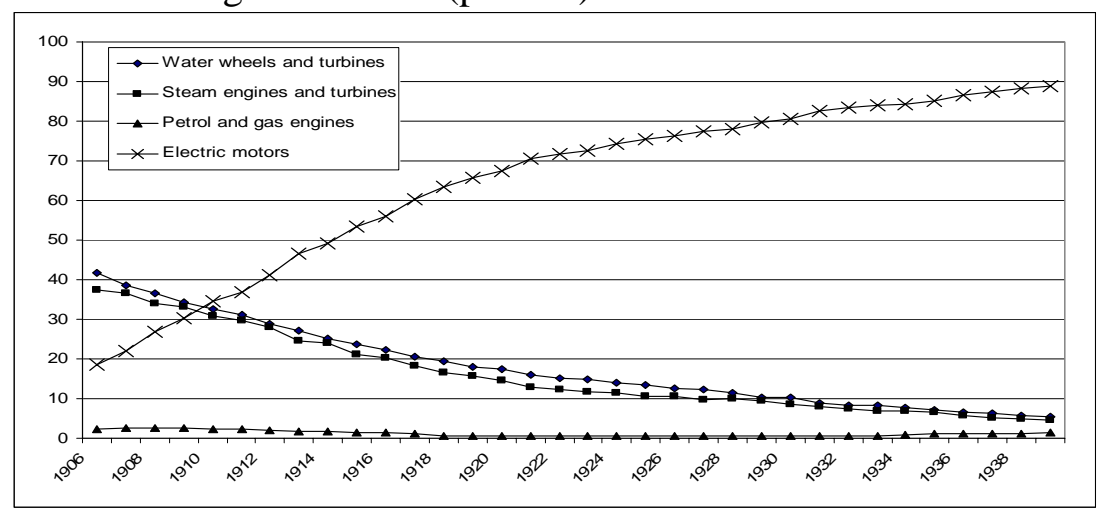

Source: Kommerskollegium (1906-39) and own calculations.

Figure 1 also shows that the relative importance of steam and water power declined considerably. In 1906, 41.6 percent of the mechanical drive in Swedish manufacturing was performed by water power. The corresponding figure for steam power was 37.6 percent. In 1939, the share of water- and steam power in the mechanical drive had fallen to 5.4 and 4.3 percent, respectively. Even though the importance of steam and water power decreased in the mechanical drive, they continued to be important producers of electricity within manufacturing. This was achieved by connecting a dynamo to the steam engine or waterwheel. When prime movers are used to generate electricity, they are called driving generators. 
Figure 2 shows the electricity generated by different types of driving generators within manufacturing. ${ }^{24}$ According to figure 2 , the power generated by prime movers within manufacturing increased considerably in 1906-39. ${ }^{25}$ Thus, hydroelectric and thermal power was rapidly transformed from being used in the direct drive into generating electricity.

Figure 2: $\quad$ Capacity generated by driving generators in Swedish manufacturing 190639 (in thousands of horsepower)

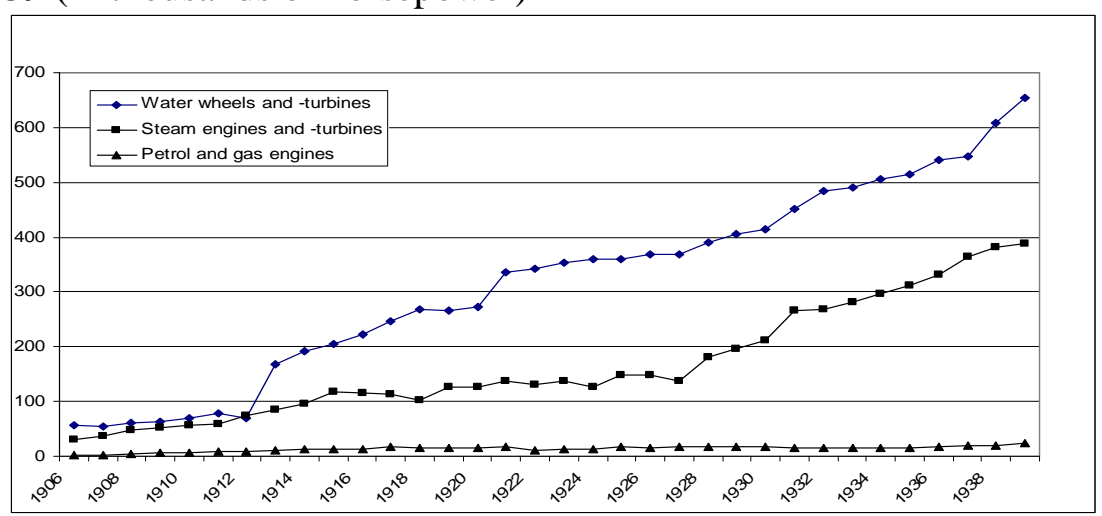

Source: Kommerskollegium (1906-39) and own calculations.

\subsection{ICT in manufacturing}

In 1947, Bardeen, Brattain and Shockley invented the transistor, which became the basis for numerous electronic innovations. Some examples are the integrated circuit and the microprocessor. Jovanovic \& Rousseau (2005) date the arrival of ICT with Intel's invention in 1971 of the "4004” microprocessor. Unfortunately, no considerable amount of data is available on the diffusion of ICT in Swedish manufacturing before the 1990s. Thus, it will be difficult to provide a thorough analysis of the diffusion of ICT in Swedish manufacturing in 1970-2005. Nonetheless, the data available will provide some insights into the diffusion of ICT in Swedish manufacturing.

\footnotetext{
${ }^{24}$ In 1906, Swedish official statistics do not distinguish between primary power used for driving generators and mechanical drive for petrol and gas engines. Therefore, it has been assumed that petrol and gas engines had the same share of driving generators and mechanical drive as in 1907.

${ }^{25}$ The change in the methodologies of collecting data for Swedish national accounts seems to have resulted in a sharp increase in the use of hydroelectric power in 1912-13. The reason might be the revision of the Swedish industry classification in 1913 (see appendix A).
} 
Figure 3 shows estimates of ICT capital as a share of the total capital stock for the business sector, manufacturing and ICT-producing industries in 1994-2002. According to figure 3, the share of ICT capital in manufacturing and the total business sector increased throughout the period. The share of ICT capital increased from 8.6 to 11.6 percent in manufacturing and from 3.4 to 4.9 percent in the business sector in 1994-2002. For ICTproducing industries, the share first decreased in 1994-98. However, it increased from 18.8 to 24.2 percent in $1998-2002 .^{26}$ Thus, ICT capital as a share of the total capital stock was at a considerably higher level in the ICT-producing industries as compared to manufacturing and the total business sector.

Figure 3: $\quad$ ICT-capital stock as a share of the Swedish total capital stock for different industries 1994-2002

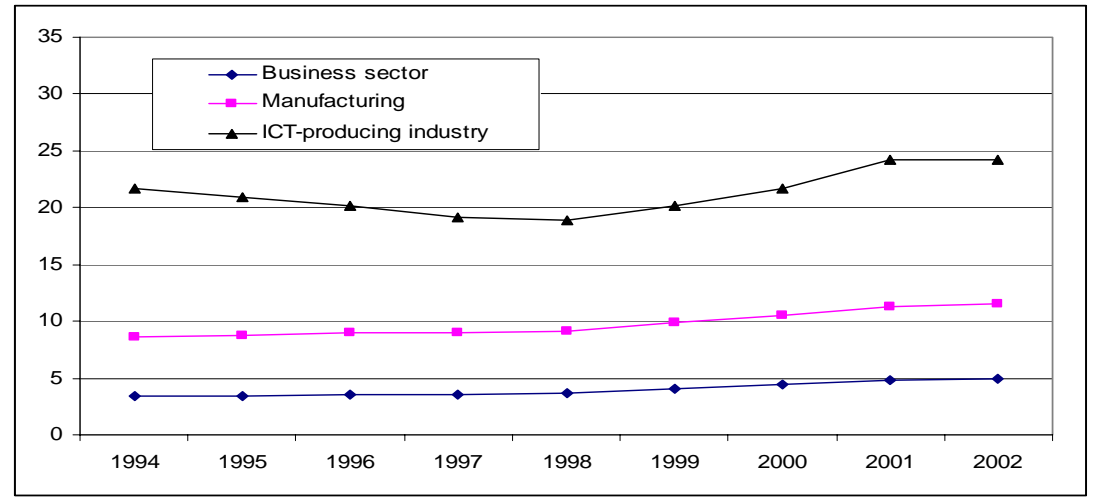

Note: The following industries are defined as ICT-producing: Office, accounting and computing machinery (ISIC 30), Electric machinery and apparatus (ISIC 31), vision and communication equipment (ISIC 32) and Medical, precision and optical instruments (ISIC 33).

Source: Statistics Sweden (2006).

There are no data available on the use of computers in Swedish enterprises before 2000. The reason for this is that Statistics Sweden did not investigate the use of ICT in Swedish firms before 2000. Table 1 shows the share of firms and employees using computers and the share of firms with internet access in manufacturing in 2000-05. The share of firms using computers was 96-99 percent in 2000-05. Moreover, in 2003-05, the share of employees working with computers was 63-65 percent, respectively. Finally, the share of

\footnotetext{
${ }^{26}$ It has not been possible to estimate ICT capital as a share of the capital at more disaggregated levels for other industries than the ICT-producing industries.
} 
manufacturing firms with access to the Internet increased from 89 percent in 2000 to 96 percent in 2005. These figures clearly indicate that by 2000, computers were well integrated in the production process of Swedish manufacturing firms. However, due to lack of earlier data, it is difficult to document how rapid the diffusion process was.

Table 1: The share of firms and employees using computers and the share of firms with Internet access in Swedish manufacturing in 2000-2005 (percent)

\begin{tabular}{l|cccccc}
\hline & 2000 & 2001 & 2002 & 2003 & 2004 & 2005 \\
\hline Firms using computers & 97 & 98 & 99 & 99 & 98 & 96 \\
& $( \pm 1)$ & $( \pm 1)$ & $( \pm 1)$ & $( \pm 1)$ & $( \pm 1)$ & $( \pm 2)$ \\
Employees using computers & n.a & n.a & n.a & 63 & 65 & 65 \\
& & & & $( \pm 4)$ & $( \pm 5)$ & $( \pm 4)$ \\
Firms with internet access & 89 & 96 & n.a & 97 & 97 & 96 \\
& $( \pm 2)$ & $( \pm 1)$ & & $( \pm 2)$ & $( \pm 2)$ & $( \pm 2)$ \\
\hline
\end{tabular}

Note: n.a = not available. Enterprises with less than 10 employees have been excluded in the investigation. Figures in parenthesis show the length of the 95\% confidence interval.

Source: Statitsics Sweden (2001-2005).

\subsection{Defining industries that were intensive users of new technology}

Section 3.1 documented how rapidly Swedish manufacturing was electrified during the first decades of the twentieth century. However, to identify which industries were intensive users of electric motors, it is necessary to also investigate the electrification process at more disaggregated industry levels. Section 2.2.1 defined intensive electric motor using industries as industries with an above median value of the average electric motor capacity as a share of mechanical drive in 1920-39. Table 2 shows the average electric motor capacity relative to the capacity of mechanical drive for 32 industries in 1914-15. ${ }^{27}$ These figures have been used to divide industries into intensive and less intensive electric motor using industries. ${ }^{28}$

\footnotetext{
${ }^{27}$ According to David (1990) it was first when approximately 50 percent of the mechanical drive capacity had been electrified that productivity started to increase. In Sweden the 50 percent level of diffusion was reached in 1914-15 (see figure 2).

${ }^{28}$ Electric machinery and cables is defined as the electric motor producing industry (see section 2.2.1).
} 
Table 2: $\quad$ Average electric motor capacity as a share of total capacity of mechanical drive in 1914-15 (percent)

\begin{tabular}{l|c}
\hline Industry & Share \\
\hline Electric motor producing industry & \\
\hline Electric machinery and cables & 98,9 \\
Intensive electric motor using industries & \\
Primary nonferrous metals & 100 \\
Printing and publishing & 95,1 \\
Bakery products & 90,3 \\
Machinery and equipment & 82,1 \\
Oil and fat & 79,7 \\
Footwear except rubber & 79,7 \\
Tobacco products & 78,8 \\
Ships and boats & 76,8 \\
Other chemical substances & 75,0 \\
Leather tanning and finishing & 71,8 \\
Fertilizers & 70,2 \\
Prepared meats & 68,2 \\
Textile mill products & 65,7 \\
Industrial chemicals & 61,2 \\
Fabricated metal products & 60,8 \\
& \\
Less intensive electric motor using industries & \\
Soap and glycerin cleaning and polishing & 58,5 \\
Glass products & 58,0 \\
Rubber products & 55,5 \\
Pulp paper and paper board & 54,5 \\
Confectionary and related products & 53,5 \\
Apparel and related product & 52,6 \\
Primary iron and steel & 49,1 \\
Cement, lime and concrete & 48,0 \\
Brewery & 46,1 \\
Paint and allied products & 45,8 \\
Other provisions & 43,4 \\
Sugar industries & 35,8 \\
Grain mill products & 27,7 \\
Spirits & 26,2 \\
Lumber products & 23,3 \\
Dairy & 12,2 \\
\hline &
\end{tabular}

Source: Kommerskollegium (1920-39) and own calculations.

According to table 2, Primary nonferrous metals, Electric machinery and cables and Printing and publishing had the highest value of electric motor capacity as a share of total mechanical drive. Dairy, Lumber products and Spirits had the lowest values. ${ }^{29}$ Table 2 shows that the difference between some of the industries classified as intensive and less intensive technology-using industries can be small. However, the average electric motor

\footnotetext{
${ }^{29}$ One reason that Grain mill products were late in adopting electric motors could be that the torque curve for steam engines were quite steep and electric motors with the same torque curves were very expensive.
} 
capacity as a share of total capacity of mechanical drive is quite large between the two different industry groups. Therefore, it is of interest to investigate whether the contribution to labor productivity growth differs between intensive and less intensive technology-using industries following electrification.

Since there are no data on the ICT capital stock available for Swedish manufacturing at a disaggregated level, it has not been possible to define which industries that are intensive users of ICT in Sweden. Therefore, the classifications pioneered by Stiroh (2002) and et al. (2003) will be used. This implies that the classification is based on data of US capital services flow. However, according to van Ark et al. (2003), ICT intensive industries in the US are also ICT intensive in some EU countries. ${ }^{30}$ Hence, it is reasonable to believe that the US ICT diffusion could also be used as a measure of ICT intensity in Swedish industries.

Table 3 presents the ICT-producing, intensive and less intensive ICT-using industries for Sweden based on van Ark et al. (2003). ${ }^{31}$ Since the ICT-producing industries also are intensive users of ICT there will be more less intensive using industries than intensive using industries

\footnotetext{
${ }^{30}$ van Ark et al. (2003) use rank correlations between the intensity of IT investments by industry to test whether ICT-intensive industries in the US are also ICT intensive in France, Germany, the Netherlands and the UK. Overall, the rankings suggest that the intensive ICT-using industries are similar across countries. ${ }^{31}$ The classification by van Ark et al. (2003) has been used since it is based on ISIC classification instead of US industry classification, which is used by Stiroh (2002).
} 
Table 3: ICT-producing, intensive ICT-using and less intensive ICT-using industries in manufacturing

\begin{tabular}{l|c}
\hline Industry & ISIC \\
\hline ICT-producing industries & 30 \\
\hline Office accounting and computing machinery & 313 \\
Insulated wire & 32 \\
Radio, television and communication equipment & $331-3$ \\
Scientific instruments & \\
Intensive ICT-using industries & 18 \\
Wearing apparel, dressing and dying of fur & 22 \\
Printing and publishing & 29 \\
Machinery and equipment & 35 \\
Other transport equipment & 31 excl. 313 \\
Other electrical machinery and apparatus nec & $334-5$ \\
Other instruments & 36 \\
Miscellaneous manufacturing & 37 \\
Recycling & \\
Less intensive ICT-using industries & $15-16$ \\
Food products & 17 \\
Textiles & 19 \\
Leather, leather products and footwear & 20 \\
Wood and products of wood and cork & 21 \\
Paper products & 23 \\
Coke, refined petroleum products and nuclear fuel & 24 \\
Chemicals & 25 \\
Rubber and plastic products & 26 \\
Non-metallic mineral products & 27 \\
Basic metals & 28 \\
Fabricated metal products & 34 \\
\hline Motor vehicles, trailers and semi-trailers & \\
\hline
\end{tabular}

Source: van Ark et al. (2003).

\section{Productivity growth in Sweden}

Section 3 showed that electric motors diffused rapidly in Swedish manufacturing in the early twentieth century. Moreover, ICT capital as a share of the total capital stock increased from 8.6 to 11.6 percent in manufacturing in 1994-2002. This section will focus on how large the productivity effect was from technology-producing, intensive and less intensive technology-using industries during electrification and the ICT revolution. 


\subsection{Productivity growth in total manufacturing}

Table 4 shows labor productivity growth in manufacturing for different subperiods in 1913-39 and 1970-2003. Since productivity growth is procyclical, the subperiods have been chosen so that productivity is measured at business cycle peaks in 1913-39 and at the bottom of the business cycle 1970-2003. ${ }^{32}$

According to table 4, productivity growth was negative in Swedish manufacturing in 1913-20. It is likely that World War I had a negative impact on productivity during this period. It was not until the 1920s that productivity started to increase in manufacturing. Annual labor productivity growth in 1920-30 was 3.9 and 4.2 percent, depending on whether production value or value added is used to measure labor productivity. The US experienced similar increases in labor productivity growth in manufacturing during the 1920s (Kendrick 1961; David 1990; 1991). During the 1930s, productivity growth in Swedish manufacturing slowed down. Annual productivity growth in manufacturing was 2.4 and 2.5 percent in 1930-39, based on production value and value added, respectively.

Table 4: $\quad$ Annual labor productivity growth in Swedish manufacturing in 1913-39 and 1970-2004, subperiods

\begin{tabular}{l|cc}
\hline Period & Production value & Value added \\
\hline & & \\
$1913-20$ & -2.8 & $-1.8 \dagger$ \\
$1920-30$ & 3.9 & $4.2 \dagger$ \\
$1930-39$ & 2.4 & $2.5 \dagger$ \\
& & \\
$1970-78$ & 1.7 & 1.7 \\
$1978-81$ & 2.4 & 2.5 \\
$1981-93$ & 4.0 & 4.0 \\
$1993-2004$ & 5.8 & 6.2 \\
& & \\
$1990-95$ & 6.5 & 6.8 \\
$1995-2000$ & 6.2 & 6.8 \\
\hline
\end{tabular}

Note: n.a = not available. $\nmid$ Data on value added in manufacturing in 1913-39 are based on Schön (1988) and include mining and Power, lightning and waterworks. For the productivity estimates based on production value, mining and Power, lightning and waterworks have been excluded.

Sources: Kommerskollegium (1913-39), Schön (1988), KLEMS (2007) and own calculations.

\footnotetext{
${ }^{32}$ The business cycle estimates are based on Edvinsson (2005). Moreover, 1913, 1970 and 2003 are not years when the business cycle peaked or touched the bottom. These years have been chosen because the time series start or end in these years.
} 
Table 4 also shows that annual labor productivity in Swedish manufacturing was 1.7 percent in 1970-78. For the periods 1978-81 and 1981-93, annual labor productivity growth in manufacturing increased to 2.4 and 4.0 percent, respectively. ${ }^{33}$ However, the large increase in productivity growth in Swedish manufacturing occurred in 1993-2004. Annual labor productivity growth for this period was 5.8 and 6.2 percent, depending on whether value added or production value is used to measure labor productivity. For the US economy, there was an increase in productivity growth beginning in the third quarter of 1995 (see Oliner \& Sichel 2000; Gordon 2000). However, labor productivity growth in Swedish manufacturing was not considerably more rapid in the period 1995-2000 as compared to the period 1990-95 (see table 4).

\subsection{The contribution of different industry groups}

A number of studies have shown there to be a lag in the implementation of new technologies and gains in productivity growth (see David 1991; Crafts 2004 (a); Edquist \& Henrekson 2006; Ristuccia \& Solomou 2002). Table 4 shows that the largest productivity growth rates in Swedish manufacturing took place in the 1920s and the 1990s for the different periods investigated. This was long after the introduction of electricity and computers in manufacturing. Thus, aggregate productivity growth increased long after the introduction of new technology for both breakthroughs. But, did the contribution to labor productivity growth differ between technology-producing, intensive technology-using and less intensive technology-using industries during the two breakthroughs?

\subsubsection{Electrification}

Tables 5 and 6 show the impact of the electric motor producing, intensive and less intensive electric motor using industries on productivity growth in Swedish manufacturing in 1920-39.

\footnotetext{
${ }^{33}$ If value added is used instead of production value the productivity growth was 2.5 for the period 197881.
} 
Table 5: Annual labor productivity growth and the contribution to labor productivity growth by industry in Swedish manufacturing, 1920-30

\begin{tabular}{l|cccc}
\hline Industry & $\begin{array}{c}\text { Annual LP } \\
\text { growth }\end{array}$ & $\begin{array}{c}\text { Industry-specific } \\
\text { contribution }\end{array}$ & $\begin{array}{c}\text { Reallocation } \\
\text { term }\end{array}$ & $\begin{array}{c}\text { Contribution } \\
\text { to LP growth }\end{array}$ \\
\hline Electric motor producing industry & $\mathbf{6 . 6}$ & $\mathbf{0 . 1 7}$ & $-\mathbf{0 . 0 3}$ & $\mathbf{0 . 1 5}$ \\
Electric machinery and cables & 6.6 & 0.17 & -0.03 & 0.15 \\
& & & & \\
Intensive electric motor using & $\mathbf{4 . 3}$ & $\mathbf{2 . 0 4}$ & $\mathbf{- 0 . 1 3}$ & $\mathbf{1 . 9 1}$ \\
industries & & & & \\
Primary nonferrous metals & 9.9 & 0.02 & 0.002 & 0.03 \\
Printing and publishing & -1.6 & $-0,05$ & $-0,02$ & -0.07 \\
Bakery products & 1.0 & 0.02 & 0.02 & 0.04 \\
Machinery and equipment & 4.1 & 0.40 & -0.07 & 0.33 \\
Oil and fat & 11.2 & 0.14 & 0.02 & 0.16 \\
Footwear except rubber & 0.7 & 0.02 & 0.006 & 0.02 \\
Tobacco products & 7.7 & 0.23 & -0.16 & 0.08 \\
Ships and boats & 8.1 & 0.15 & 0.01 & 0.16 \\
Other chemical substances & 6.9 & 0.09 & 0.001 & 0.09 \\
Leather tanning and finishing & 2.9 & 0.05 & -0.01 & 0.03 \\
Fertilizers & 7.6 & 0.05 & 0.003 & 0.05 \\
Prepared meats & 8.6 & 0.19 & 0.05 & 0.24 \\
Textile mill products & 4.7 & 0.45 & 0.05 & 0.49 \\
Industrial chemicals & 8.0 & 0.10 & 0.005 & 0.10 \\
Fabricated metal products & 3.5 & 0.18 & -0.03 & 0.15 \\
& & & & \\
Less intensive electric motor using & $\mathbf{4 . 1}$ & $\mathbf{2 . 2 8}$ & $-\mathbf{0 . 0 8}$ & $\mathbf{2 . 2 0}$ \\
industries & & & & \\
Soap and glycerin cleaning and & 8.7 & 0.16 & -0.01 & 0.15 \\
polishing & & & & \\
Glass products & & & & \\
Rubber products & 2.6 & 0.02 & 0.004 & 0.03 \\
Pulp paper and paper board & 2.6 & 0.03 & -0.01 & 0.02 \\
Confectionary and related products & 7.3 & 0.82 & 0.03 & 0.85 \\
Apparel and related product & 3.8 & 0.04 & 0.01 & 0.05 \\
Primary iron and steel & 3.3 & 0.06 & -0.08 & -0.02 \\
Cement, lime and concrete & 4.6 & 0.17 & 0.01 & 0.18 \\
Brewery & 4.5 & 0.12 & -0.10 & 0.03 \\
Paint and allied products & 3.3 & 0.08 & 0.001 & 0.08 \\
Other provisions & 8.2 & 0.02 & 0.00005 & 0.02 \\
Sugar industries & 0.2 & 0.004 & 0.03 & 0.03 \\
Grain mill products & 4.8 & 0.23 & -0.04 & 0.19 \\
Spirits & 2.5 & 0.11 & -0.01 & 0.10 \\
Lumber products & 4.4 & 0.08 & -0.01 & 0.08 \\
Dairy & 1.2 & 0.10 & 0.02 & 0.12 \\
Residual & 6.4 & 0.22 & 0.06 & 0.29 \\
Total & & & & $-\mathbf{0 . 3 3}$ \\
\hline & & & & $\mathbf{3 . 9 3}$ \\
\hline & & & &
\end{tabular}

Note: Labor productivity is defined as production value per person employed.

Source: Kommerskollegium (1920-30) and own calculations. 
According to table 5, the annual contribution of the electric motor producing industry was 0.15 percentage points of the annual labor productivity growth of 3.93 percent in 1920-30. The corresponding figures for the intensive and less intensive electric motor using industries were 1.91 and 2.20 percentage points. Thus, the less intensive electric motor using industries contributed more to productivity growth than intensive using industries.

Productivity growth for intensive electric motor using industries was 4.3 percent, compared to 4.1 percent for less intensive electric motor using industries. Hence, productivity growth was slightly higher in industries using electric motors more intensively. ${ }^{34}$ Moreover, productivity growth in the electric motor producing industry was 6.6 percent. Thus, the electric motor producing industry had a higher productivity growth than the intensive and less intensive electric motor using industries.

Oil and fat, Primary nonferrous metals and Soap and glycerine cleaning and polishing had the highest annual productivity growth in 1920-30. However, the industry contributing most to labor productivity growth was Pulp, paper and paper board with an annual contribution of 0.85 percentage points in 1920-30. Printing and publishing, Other provisions and Footwear except rubber had the lowest productivity growth in 1920-30. Moreover, the reallocation term was negative for all three different industry groups. Thus, on average, labor input increased in sectors with a lower level of labor productivity growth. However, the combined effect of the reallocation term was quite small as compared to the industry-specific contribution (see table 5).

\footnotetext{
${ }^{34} \mathrm{~A}$ simple OLS regression has been run where the dependent variable is labor productivity growth and the independent variable a dummy taking 1 for electric motor intensive industries and 0 for other industries. The results show that labor productivity growth does not differ significantly in intensive electric motor using industries compared to less intensive electric motor using industries.
} 
Table 6: Annual labor productivity growth and the contribution to labor productivity growth by industry in Swedish manufacturing, 1930-39

\begin{tabular}{|c|c|c|c|c|}
\hline Industry & $\begin{array}{l}\text { Annual LP } \\
\text { growth }\end{array}$ & $\begin{array}{c}\text { Industry-specific } \\
\text { contribution }\end{array}$ & $\begin{array}{l}\text { Reallocation } \\
\text { term }\end{array}$ & $\begin{array}{l}\text { Contribution } \\
\text { to LP growth }\end{array}$ \\
\hline Electric motor producing industry & 3.0 & 0.11 & -0.06 & 0.05 \\
\hline Electric machinery and cables & 3.0 & 0.11 & -0.06 & 0.05 \\
\hline $\begin{array}{l}\text { Intensive electric motor using } \\
\text { industries }\end{array}$ & 2.2 & 1.12 & -0.14 & 0.98 \\
\hline Primary nonferrous metals & 11.6 & 0.08 & 0.03 & 0.11 \\
\hline Printing and publishing & -0.6 & -0.02 & -0.05 & -0.07 \\
\hline Bakery products & 2.0 & 0.04 & 0.01 & 0.05 \\
\hline Machinery and equipment & 2.6 & 0.35 & -0.28 & 0.07 \\
\hline Oil and fat & -5.8 & -0.06 & 0.02 & -0.04 \\
\hline Footwear except rubber & 0.5 & 0.01 & 0.003 & 0.01 \\
\hline Tobacco products & 3.1 & 0.09 & -0.02 & 0.07 \\
\hline Ships and boats & 4.3 & 0.09 & -0.02 & 0.07 \\
\hline Other chemical substances & 1.2 & 0.02 & 0.03 & 0.05 \\
\hline Leather tanning and finishing & -0.04 & -0.0005 & 0.01 & 0.01 \\
\hline Fertilizers & 2.4 & 0.01 & 0.0008 & 0.01 \\
\hline Prepared meats & 2.3 & 0.07 & 0.19 & 0.26 \\
\hline Textile mill products & 2.5 & 0.24 & 0.02 & 0.26 \\
\hline Industrial chemicals & 2.9 & 0.02 & 0.01 & 0.03 \\
\hline Fabricated metal products & 2.8 & 0.18 & -0.09 & 0.09 \\
\hline $\begin{array}{l}\text { Less intensive electric motor using } \\
\text { industries }\end{array}$ & 3.0 & 1.41 & 0.002 & 1.41 \\
\hline $\begin{array}{l}\text { Soap and glycerin cleaning and } \\
\text { polishing }\end{array}$ & 6.2 & 0.11 & 0.05 & 0.16 \\
\hline Glass products & 4.3 & 0.04 & -0.01 & 0.02 \\
\hline Rubber products & 10.1 & 0.14 & -0.03 & 0.11 \\
\hline Pulp paper and paper board & 3.8 & 0.39 & -0.0004 & 0.39 \\
\hline Confectionary and related products & 4.3 & 0.05 & 0.01 & 0.06 \\
\hline Apparel and related product & 3.4 & 0.08 & -0.15 & -0.07 \\
\hline Primary iron and steel & 1.7 & 0.08 & -0.02 & 0.05 \\
\hline Cement, lime and concrete & 5.4 & 0.14 & 0.02 & 0.17 \\
\hline Brewery & 1.8 & 0.04 & 0.0006 & 0.04 \\
\hline Paint and allied products & 5.2 & 0.02 & 0.01 & 0.03 \\
\hline Other provisions & 3.1 & 0.06 & 0.07 & 0.13 \\
\hline Sugar industries & 5.8 & 0.16 & -0.01 & 0.15 \\
\hline Grain mill products & 0.8 & 0.02 & -0.003 & 0.02 \\
\hline Spirits & -0.8 & -0.01 & 0.003 & -0.01 \\
\hline Lumber products & -0.7 & -0.04 & 0.02 & -0.01 \\
\hline Dairy & 2.9 & 0.11 & 0.05 & 0.16 \\
\hline Residual & & & & -0.07 \\
\hline Total & 2.37 & & & 2.37 \\
\hline
\end{tabular}

Note: Labor productivity is defined as production value per person employed.

Source: Kommerskollegium (1930-39) and own calculations. 
According to table 6, the contribution from the electric motor producing industry was 0.05 percentage points of the annual productivity growth of 2.37 percent in $1930-39$. The corresponding figures for intensive and less intensive electric motor using industries were 0.98 and 1.41 percentage points. Once again, less intensive electric motor using industries contributed more to productivity growth than intensive electric motor using industries. Moreover, annual labor productivity growth was 3.0 percent for industries using electric motors less intensively as compared to 2.2 percent for intensive users of electric motors. Productivity growth in the industry producing electric motors was 3.0 percent.

Primary nonferrous metals, Rubber products and Soap and glycerin cleaning and polishing had the highest annual labor productivity growth rates. Pulp, paper and paper board continued to contribute most to labor productivity growth in Swedish manufacturing in 1930-39. Moreover, Oil and fat, and Spirits and Lumber products had the lowest labor productivity growth in 1930-39. The reallocation term was small in relation to the industry-specific contribution. However, for some industries, such as Machinery and equipment, the reallocation term was quite large. ${ }^{35}$

\subsubsection{The ICT revolution}

Table 7 shows the contribution of ICT-producing, intensive and less intensive ICT-using industries to annual labor productivity growth in Swedish manufacturing in 1993-2004. The annual contribution of ICT-producing industries to labor productivity growth was 2.18 percentage points of the annual productivity growth of 5.78 percent in manufacturing. The corresponding figures for intensive and less intensive ICT-using industries were 0.80 and 2.88 percentage points. Labor productivity growth was 16.0 percent for ICT-producing industries as compared to 3.6 and 4.2 percent for intensive and less intensive ICT-using industries. Moreover, the reallocation term was quite small for all three different industry groups.

\footnotetext{
${ }^{35}$ The reason for this is that the productivity level for Machinery and equipment was lower than the average productivity level for manufacturing. Thus, when labor resources increased in Machinery and equipment, there was a negative effect on aggregate productivity growth.
} 
Table 7: $\quad$ Annual labor productivity growth and the contribution to labor productivity growth by industry in Swedish manufacturing, 1993-2004

\begin{tabular}{|c|c|c|c|c|}
\hline Industry & $\begin{array}{l}\text { Annual LP } \\
\text { growth }\end{array}$ & $\begin{array}{c}\text { Industry-specific } \\
\text { contribution }\end{array}$ & $\begin{array}{c}\text { Reallocati } \\
\text { on term }\end{array}$ & $\begin{array}{l}\text { Contribution } \\
\text { to LP growth }\end{array}$ \\
\hline ICT-producing industries & 16.0 & 2.20 & -0.02 & 2.18 \\
\hline $\begin{array}{l}\text { Office accounting and computing } \\
\text { machinery }\end{array}$ & 7.2 & 0.03 & 0.01 & 0.04 \\
\hline Insulated wire & 1.2 & 0.01 & -0.01 & -0.002 \\
\hline $\begin{array}{l}\text { Radio, television and communication } \\
\text { equipment }\end{array}$ & 24.6 & 2.03 & -0.02 & 2.01 \\
\hline Scientific instruments & 4.8 & 0.13 & -0.01 & 0.12 \\
\hline Intensive ICT-using industries & 3.6 & 0.73 & 0.07 & 0.80 \\
\hline $\begin{array}{l}\text { Wearing apparel, dressing and dying } \\
\text { of fur }\end{array}$ & 5.1 & 0.01 & 0.002 & 0.01 \\
\hline Printing and publishing & 2.5 & 0.13 & 0.05 & 0.18 \\
\hline Machinery and equipment & 4.6 & 0.51 & -0.01 & 0.49 \\
\hline Other transport equipment & -4.4 & -0.10 & 0.001 & -0.10 \\
\hline $\begin{array}{l}\text { Other electrical machinery and } \\
\text { apparatus nec }\end{array}$ & -0.1 & -0.0001 & -0.01 & -0.01 \\
\hline Other instruments & 3.2 & 0.07 & 0.002 & 0.07 \\
\hline Miscellaneous manufacturing & 4.0 & 0.10 & 0.03 & 0.13 \\
\hline Recycling & 3.6 & 0.01 & 0.01 & 0.02 \\
\hline Less intensive ICT-using industries & 4.2 & 2.87 & 0.01 & 2.88 \\
\hline$\overline{\text { Food products }}$ & 2.2 & 0.22 & -0.03 & 0.19 \\
\hline Textiles & 2.8 & 0.02 & 0.01 & 0.03 \\
\hline Leather, leather products and footwear & 3.8 & 0.004 & 0.0007 & 0.01 \\
\hline Wood and products of wood and cork & 4.2 & 0.20 & 0.001 & 0.20 \\
\hline Paper products & 3.8 & 0.31 & -0.03 & 0.29 \\
\hline $\begin{array}{l}\text { Coke, refined petroleum products and } \\
\text { nuclear fuel }\end{array}$ & 0.1 & 0.004 & 0.03 & 0.03 \\
\hline Chemicals & 5.2 & 0.40 & 0.01 & 0.41 \\
\hline Rubber and plastic products & 3.5 & 0.09 & -0.01 & 0.08 \\
\hline Non-metallic mineral products & 3.4 & 0.06 & 0.01 & 0.07 \\
\hline Basic metals & 3.5 & 0.23 & 0.001 & 0.23 \\
\hline Fabricated metal products & 2.5 & 0.15 & -0.05 & 0.10 \\
\hline $\begin{array}{l}\text { Motor vehicles, trailers and semi- } \\
\text { trailers }\end{array}$ & 8.9 & 1.18 & 0.06 & 1.24 \\
\hline Residual & & & & -0.08 \\
\hline Total manufacturing & 5.78 & & & 5.78 \\
\hline
\end{tabular}

Note: Labor productivity is defined as production value per person engaged.

Source: KLEMS (2007) and own calculations.

The Radio, television and communication equipment (RTC) industry had a very high labor productivity growth with 24.6 percent per year in 1993-2004. Moreover, the contribution of the RTC industry to total labor productivity growth in manufacturing was 
2.01 percentage points, or approximately 35 percent of total labor productivity growth in 1993-2004. This implies that the RTC industry had the highest productivity growth rate and contributed most to total labor productivity growth in 1993-2004. The industry with the second highest contribution was Motor vehicles, trailers and semi-trailers, which contributed 1.24 percentage points. Thus, the RTC industry and the Motor vehicles, trailers and semi-trailers accounted for 57 percent of total annual productivity growth in Swedish manufacturing in 1993-2004.

\subsection{Comparing electrification and the ICT revolution}

Table 8 shows the relative contribution to labor productivity growth and the relative size of technology-producing, intensive and less intensive technology-using industries for subperiods in 1920-39 and 1993-2004. According to table 8, the relative contribution and size of the electric motor producing industry was relatively small in 1920-30 and 1930-39. The contribution was only 3.4 and 2.0 percent of total labor productivity growth. Moreover, the relative contribution from the intensive electric motor using industries were 45 and 40 percent during the two periods, while the corresponding figures for the less intensive electric motor using industries were approximately 52 and 58 percent, respectively.

Compared to their relative size the contribution to productivity growth from all industry groups was approximately the same in 1920-30. However, in 1930-39 the contribution from the less intensive technology-using industries was considerably larger than its relative size. Thus, the relative contribution from the less intensive electric motor producing industry was primarily due to a higher than average productivity growth. 
Table 8: $\quad$ Relative productivity contribution and size by each industry group in Swedish manufacturing, subperiods

\begin{tabular}{l|ccc}
\hline & $1920-30$ & $1930-39$ & $1993-2004$ \\
\hline Relative contribution & & & \\
Technology-producing & 3.4 & 2.0 & 37.2 \\
Intensive technology-using & 45.0 & 40.2 & 13.7 \\
Less intensive technology-using & 51.6 & 57.8 & 49.2 \\
Total & 100 & 100 & 100 \\
& & & \\
Relative size & 3.1 & 4.1 & 11.6 \\
Technology-producing & 47.9 & 51.4 & 28.0 \\
Intensive technology-using & 49.0 & 44.5 & 60.3 \\
Less intensive technology-using & 100 & 100 & 100 \\
Total & & \\
\hline
\end{tabular}

Note: Labor productivity is defined as production value per person employed in 1920-39 and production value per person engaged in 1993-2004. The relative size is an equal weighted average of the average relative share of production value and labor compensation for each industry. To make comparisons possible, residuals have been excluded from the relative contribution.

Sources: Kommerskollegium (1920-39), KLEMS (2007) and own calculations.

The relative contribution from the ICT-producing industries was 37.2 percent in 19932004. While the corresponding figures for intensive and less intensive ICT-using industries were 13.7 and 49.2 percent. The contribution from less intensive ICT-using industries can be explained by its relative large size and not primarily by a considerably higher productivity growth. However, the contribution from the ICT-producing industries was considerably larger than its relative size. Moreover, in relative terms the ICT producing industry contributed more than 17 times as much to productivity growth in 1993-2004 compared to the electric motor producing industry in 1930-39. However, the ICT-producing industries was only 3 times as large as the electric motor producing industry in relative terms. Hence, the relative contribution of the technology-producing industry was considerably larger during the ICT revolution as compared to electrification.

One reason to the high productivity growth in the ICT-producing industries is that the RTC industry had a much higher productivity growth than Electric machinery and cables. Productivity growth in the Swedish RTC industry was 24.6 percent in 1993-2004, while 
the corresponding figure for Electric machinery and cables was 6.6 and 3.0 percent in 1920-30 and 1930-39, respectively.

Another difference between electrification and the ICT-revolution is that the contribution to productivity growth from the intensive technology-using industries during electrification was considerably larger than during the ICT-revolution. However, most of the difference can be explained by the relative small size of the intensive ICT-using industries. Thus, the difference is not explained by a major difference in productivity growth during the two GPTs. As pointed out by Daveri (2004), the way technologyintensive industries are classified can have large impacts on the results depending of the size of different industry groups. Nonetheless, the results presented in table 8 clearly show that the technology-producing industry was considerably more important for productivity growth during the ICT revolution despite its size effect.

According to Pilat \& Devlin (2004), the share of ICT-producing industries is relatively large in Sweden compared to many other countries. This raises questions of whether the large contribution to labor productivity growth of the ICT-producing industries is an exclusively Swedish phenomenon or if ICT-producing industries have contributed substantially to labor productivity growth also in other counties?

Table 9 shows labor productivity growth, contribution and relative contribution to labor productivity growth from each industry group in France, Germany, the UK and the US. 
Table 9: Annual labor productivity growth, contribution and relative contribution to labor productivity growth in manufacturing in four countries 1995-2004

\begin{tabular}{l|cccc}
\hline & France & Germany & UK & US \\
\hline Annual labor productivity growth & & & & \\
ICT-producing industries & 15.0 & 6.7 & 5.5 & 21.7 \\
Intensive ICT-using industries & 1.9 & 1.8 & 2.8 & 2.6 \\
Less intensive ICT-using industries & 2.7 & 1.7 & 1.8 & 2.6 \\
Total manufacturing & 3.34 & 2.22 & 2.66 & 4.88 \\
& & & & \\
Contribution to LP growth & & & & \\
ICT-producing industries & 1.12 & 0.45 & 0.48 & 2.81 \\
Intensive ICT-using industries & 0.59 & 0.63 & 0.91 & 0.78 \\
Less intensive ICT-using industries & 1.72 & 0.99 & 1.06 & 1.49 \\
Residual & -0.09 & 0,15 & 0.22 & -0.19 \\
& & & & \\
Total manufacturing & 3.34 & 2.22 & 2.66 & 4.88 \\
& & & & \\
Relative contribution & & & & \\
ICT-producing industries & 32.6 & 21.9 & 19.5 & 55.4 \\
Intensive ICT-using industries & 17.3 & 30.4 & 37.1 & 15.3 \\
Less intensive ICT-using industries & 50.2 & 47.7 & 43.4 & 29.3 \\
& & & & \\
Total manufacturing & 100 & 100 & 100 & 100 \\
\hline
\end{tabular}

Note: Residuals have been excluded from the relative contribution. Labor productivity growth is defined as value added per person engaged. National deflators are used for all industries including the ICT-producing industries.

Source: KLEMS (2007).

According to table 9, the only country where the contribution of ICT-producing manufacturing to labor productivity growth was higher than in Sweden, in absolute terms, was the US. The US ICT-producing industries accounted for 2.81 percentage points of the annual 4.88 percent labor productivity growth in manufacturing in 1995-2004. The corresponding figure for Sweden was 2.18 percentage points of the 5.78 percent annual labor productivity growth in manufacturing in 1993-2004 (see table 7). ${ }^{36}$ Even though the contribution of the ICT-producing industries to labor productivity growth, in absolute terms, is lower in the other three European countries, the relative contribution is quite high for these countries. According to table 9, the relative contribution was 32.6, 21.9 and 19.5 percent in France, Germany and the UK, respectively. Hence, the ICT-

\footnotetext{
${ }^{36}$ US labor productivity growth is defined as value added per person engaged, while the Swedish labor productivity figures are defined as production value per person engaged.
} 
producing industries accounted for a large part of labor productivity growth in manufacturing in these countries.

\subsection{Services}

So far, this paper has focused on productivity growth in manufacturing. The primary reason for this is that there are no reliable estimates of productivity growth for the service sector during electrification. Moreover, characteristics of services tend to change frequently and services are often tailored to each customer's individual needs. Thus, it is very difficult to measure the quality improvement of services and productivity measures of services are therefore often questioned. Nonetheless, in 2004, the production value of the service sector accounted for 51 percent of the production value of the total Swedish business sector. The corresponding figure for manufacturing was 39 percent. Thus, despite the difficulties in measuring productivity in services, it is important to use the available data to test whether the same conclusions about the productivity growth pattern are valid also when productivity estimates for services are included.

Table 10 shows the contribution of ICT-producing, intensive and less intensive ICT-using industries for the whole business sector in Sweden and the US in 1993-2004. The figures for Sweden must be interpreted with great caution since accurate price indexes are missing for many Swedish services. For those services where price indexes are missing, Statistics Sweden uses the change of wages in each service sector to estimate production value and value added in fixed prices.

According to table 10, US labor productivity growth was higher in the intensive ICTusing industries, compared to the corresponding industry in Sweden. Labor productivity growth in Swedish and US intensive ICT-using industries was 1.9 and 3.4 percent, respectively. Moreover, annual Swedish labor productivity growth was 10.1 percent for ICT-producing industries compared to 7.2 percent for the corresponding industry in the US. Moreover, Swedish labor productivity growth was higher than that in the US in less 
intensive ICT-using industries. Altogether, annual productivity growth in the Swedish and US business sector in 1993-2004 was 2.74 and 2.32 percent, respectively.

In absolute terms, the contribution to labor productivity growth was 1.11 percentage points in US intensive ICT-using industries, while the corresponding figure for Sweden was 0.46 percentage points. Hence, the relative contribution of intensive ICT-using industries was 38.8 percent in the US compared to 14.8 percent for Sweden. However, the relative contribution from ICT-producing industries was higher in Sweden compared to the US.

Table 10: Annual LP growth, contribution and relative contribution to LP growth in the Swedish and the US business sector in 1993-2004

\begin{tabular}{l|cc}
\hline & Sweden & US \\
\hline Annual labor productivity growth & & 7.2 \\
ICT-producing industries & 10.1 & 3.4 \\
Intensive ICT-using industries & 1.9 & 1.7 \\
Less intensive ICT-using industries & 2.6 & 2.32 \\
& & \\
Total business sector & 2.74 & 0.65 \\
Contribution to LP growth & & 1.11 \\
ICT-producing industries & 1.01 & 1.10 \\
Intensive ICT-using industries & 0.46 & -0.54 \\
Less intensive ICT-using industries & 1.63 & 2.32 \\
Residual & -0.36 & \\
& & \\
Total business sector & 2.74 & 22.6 \\
& & 38.8 \\
Relative contribution & 32.6 & 38.6 \\
ICT-producing industries & 14.8 & 100 \\
Intensive ICT-using industries & 52.8 & \\
Tess intensive ICT-using industries & & \\
Total business sector & 100 & \\
\hline
\end{tabular}

Note: Residuals have been excluded from the relative contribution. Labor productivity growth is defined as production value per person engaged. National deflators are used for all industries. The definitions of ICTproducing industries, intensive and less intensive ICT-using industries are based on van Ark et al. (2003).

Sources: KLEMS (2007).

These results correspond well with the findings of van Ark et al. (2003) which investigate the differences in service sector productivity growth between the US and EU-countries. According to van Ark et al. (2003), the largest difference between Europe and the US can 
be found for ICT-intensive services in 1995-2000. This can be explained by a much higher productivity growth for US Retail and wholesale trade and Financial services compared to the corresponding industries in most EU-countries.

Table 10 shows that the contribution of ICT-producing manufacturing industries to labor productivity growth remains very high both in Sweden and the US when services are included. The relative contribution to labor productivity growth from Swedish ICTproducing industries was 32.6 percent of the total business sector, while the corresponding figure for the US was 22.6 percent. Hence, even when services are included, the contribution to labor productivity growth of the technology-producing industry is considerably higher during the ICT revolution than during electrification in Sweden in 1920-39.

\subsection{Measurement errors}

In section 4.2, it was shown that productivity growth was higher in ICT-producing industries in the 1990s compared to productivity in the industry producing electric motors in 1920-39. One of the reasons for this is the tremendous improvement in the technology of ICT products since the introduction of the microprocessor in the 1970s. According to many empirical observations, the number of transistors per square inch of an integrated circuit has doubled every 18 months since the 1970 s. $^{37}$ To capture the fast quality improvements of ICT products, many statistical agencies started to use hedonic price indexes for ICT products in the 1990s. ${ }^{38}$ The hedonic methodology is extensively used for ICT products in the US, while European countries have been slower in adopting hedonic methods (van Mulligen 2003). In Sweden, hedonic price indexes are used for imported PCs, but not for telecommunication equipment products.

\footnotetext{
${ }^{37}$ This empirical observation is often refereed to as Moore's law after the co-founder of Intel Gordon E. Moore.

${ }^{38}$ A hedonic price index is a price index making use of a hedonic function. A hedonic function is a relation between the prices of different product models, such as the various models of personal computers, and the quantities of characteristics in them (Triplett 2004).
} 
When hedonic price indexes are not used, statistical agencies use matched model price indexes. The matched model is constructed comparing exactly the same model of specific products in two time periods. The price index is computed by matching the price for the second period with that in the initial period. Models that cannot be matched are excluded. When statistical agencies match models based on different assessments, they also introduce a quality bias. This quality bias comes in two forms: inside and outside the sample bias. The inside type of bias occurs when prices of non-identical products are matched. The outside kind of bias occurs when price changes of matched models are not representative of price changes of unmatched models. This bias is often strong, if the share of matched models is low (van Mulligen 2003).

The largest productivity growth in Swedish ICT-producing industries took place in the RTC industry. Hedonic price indexes are not used for this industry, but it is likely that the use of the matched model methodology to measure price changes for telecommunication equipment products give rises to large inside and outside the sample bias. Many telecommunication products are sold as large complex systems and are often tailor made for customers. Moreover, Edquist (2005a) shows that the methods used to deflate intermediate inputs such as semiconductors can have a large effect on the measured productivity growth in the RTC industry. ${ }^{39}$

The price indexes used for Electric machinery and cables are matched model price indexes based on Ljungberg (1990). At a more disaggregated level, Electric machinery and cables (1) consists of Electric machinery (1a) and Electric cables and electronic apparatus (1b). Edquist (2005b) has constructed hedonic price indexes for Electric machinery (1a). He finds that during the 1920s, PPI-deflated hedonic price indexes decreased by 4.8 percent per year. This is a clear indication of rapid productivity growth in the electric motor producing industry in Sweden during the 1920s. If the hedonic price indexes provided by Edquist are used to calculate labor productivity growth for Electric machinery (1a) in 1920-30, annual labor productivity growth becomes 14.8 percent.

\footnotetext{
${ }^{39}$ The findings of Edquist (2005a) are only valid as long as value added is used to estimate productivity growth for the RTC industry. When production value is used instead of value added, there are no separate price indexes for intermediate inputs.
} 
What would the effect on labor productivity be if these price indexes were used to calculate labor productivity growth for Electric machinery and cables (1)?

Table 11 shows annual labor productivity growth, contribution and relative contribution for Electric machinery and cables (1) when the hedonic price indexes for electric motors based on Edquist (2005b) are used. The calculations use a price index for Electric cables and electronic apparatus (1b) based on Ljungberg. ${ }^{40}$ According to table 11, annual labor productivity growth of Electric machinery and cables (1) increases from 6.6 percent to 9.0 percent, when hedonic price indexes are used.

Table 11: Annual labor productivity growth, contribution and relative contribution to labor productivity growth for Swedish Electric machinery and cables based on different price indexes in 1920-30

\begin{tabular}{l|c}
\hline & \\
\hline Electric machinery and cables (matched model price indexes based on & $1920-30$ \\
Ljungberg 1990) & 6.6 \\
LP growth & 0.15 \\
Contribution to LP growth & 3.4 \\
Relative contribution to LP growth & \\
Electric machinery and cables (hedonic price indexes for electric & \\
motors based on Edquist 2005b) $\dagger$ & 9.0 \\
LP growth & 0.21 \\
Contribution to LP growth & 4.8 \\
Relative contribution to LP growth & \\
\hline
\end{tabular}

Note: Electric machinery and cables (1) consists of Electric machinery (1a) and Cables and electronic apparatus (1b). †The productivity growth estimates for Electric Machinery (1a) are based on hedonic price indexes provided by Edquist (2005b), while the estimates for Cables and electronic apparatus (1b) are based on matched model price indexes provided by Ljungberg (1990). The price index for Cables and electronic apparatus (1b) is an equally weighted price index of two different electric cables, named OVI and HVG (see Ljungberg 1990 p. 319).

Sources: Ljungberg (1990), Edquist (2005b) and own calculations.

Nonetheless, the increase in contribution and relative contribution to labor productivity growth is moderate. The relative contribution increases from 3.4 percent of annual total labor productivity growth to 4.8 percent when hedonic price indexes are used for Electric machinery. The corresponding figure for the ICT-producing industries was 37.2 percent

\footnotetext{
${ }^{40}$ The price index of cables and electronic apparatus is based on the price development of two different cables, named OVI and HVG (see Ljungberg 1990). The two price indexes have been equally weighted.
} 
in 1993-2004 (see table 8). Hence, the relative impact of the technology-producing industry on labor productivity growth was considerably higher during the ICT revolution than during electrification, even when hedonic price indexes are used.

\section{Conclusions}

Swedish manufacturing was rapidly electrified in the early twentieth century. In 1906, electric motors accounted for 18.6 percent of the mechanical drive capacity in Swedish manufacturing, while the corresponding figure in 1939 was 88.9 percent. Hence, the share of thermal and hydroelectric power used for mechanical drive decreased as steam engines and water wheels were transformed into driving generators. These findings support earlier investigations of the diffusion of electricity in Swedish manufacturing (see Hjulström 1940; Schön 1990). However, horsepower capacity does not always reflect the work output and therefore, it is likely that the electrification of manufacturing was not as rapid as suggested by Swedish capacity data. According to Du Boff (1979), the capacity utilization of electric motors was lower compared to steam engines. Hence, there is reason to believe that the electrification of the direct mechanical drive in Swedish manufacturing was somewhat slower in terms of capacity utilization.

For the period 1980-1999, there is a lack of data on the diffusion of ICT products in Swedish manufacturing. Still, it was possible to show that ICT as a share of the capital stock in Swedish manufacturing increased from 8.6 percent in 1994 to 11.6 percent in 2002. In 2000, the share of firms using computers was 96-99 percent and by 2003, more than 60 percent of all employees in Swedish manufacturing firms were working with computers. Moreover, the share of manufacturing firms with access to the Internet increased from 89 percent in 2000 to 96 percent in 2005. Hence, by 2000, computers were well integrated in the production process of Swedish manufacturing firms.

Stiroh (2002) defines the ICT intensive industries in the US as those industries with an above median value of the 1995 ICT share of capital services. The industries with below 
median value are defined as less intensive ICT-using industries. The classification of Swedish ICT-producing, intensive and less intensive using industries is based on Stiroh (2002) and the ICT-producing industries are defined according to OECD (2002). ${ }^{41}$ During electrification, industries with an above median value of the average electric motor capacity as a share of total mechanical drive capacity in 1920-39 was defined as intensive users of electric motors. This definition is a good indication of how far the process of replacing old production equipment had proceeded in each industry. According to Devine (1983) and David (1991), the replacement of old production by installing electric motors resulted in a number of productivity enhancing opportunities.

To measure the contribution of each industry to labor productivity growth, the decomposition method recommended by OECD (2001) was used (see section 2.2.3). Annual labor productivity growth in the electric motor producing industry was 6.6 and 3.0 in 1920-30 and 1930-39, respectively. The corresponding figures for the intensive and less intensive electric motor using industries were 4.3 and 4.1 percent in 1920-30 and 2.2 and 3.0 percent in 1930-39. Thus, labor productivity growth was slightly higher for the electric motor producing industry, compared to the intensive and less intensive electric motor using industries in 1920-30.

The relative contribution to labor productivity growth in manufacturing from the electric motor producing industry was only 3.4 percent compared to 45.0 and 51.6 percent for the intensive and less intensive electric motor using industries in 1920-29. In 1930-39, the relative contribution decreased to 2 percent for the electric motor producing industry. The relative for intensive and less intensive using industries was 40.2 and 57.8 percent in 1930-39. In 1920-30, the difference in size and contribution between the different industries was small. However, in 1930-39 the relative contribution to productivity growth was larger than the relative size of the less intensive electric motor using industries, indicating a higher productivity growth rate.

\footnotetext{
${ }^{41}$ Since there were no data of the ICT capital stock available for Swedish manufacturing, it has not been possible to identify which industries that are intensive users of ICT in Sweden. Hence, the classification must be based on US data provided by Stiroh (2002). However, van Ark et al. (2003) suggest that the intensive ICT-using industries are similar in the US and a number of European countries.
} 
For the ICT revolution, annual labor productivity growth was 16.0 percent for the ICTproducing industries, compared to 3.6 and 4.2 percent for the intensive and less intensive ICT-using industries in 1993-2004. The relative contribution to labor productivity growth in manufacturing was 37.2 percent for the ICT-producing industries. The corresponding figures for the intensive and less intensive ICT-using industries were 13.7 and 49.2 percent. Both the intensive and less intensive ICT-using industries contributed less to productivity growth compared to their size in relative terms. However, the ICTproducing industries contributed considerably more to productivity growth compared to its relative size. Thus, the relative productivity effect from the ICT-producing industries was largely due to a considerably higher productivity growth in this industry.

The comparison of productivity growth following electrification and the ICT revolution show that the impact of the technology-producing industry in manufacturing was considerably larger following the ICT revolution compared to electrification. The contribution from the ICT-producing industries to labor productivity growth is considerably larger also when the relative size is taken into account. In relative terms the ICT-producing industries contributed more than 17 times as much to productivity growth in 1993-2004 compared to the electric motor producing industry in 1930-39. However, the size of the ICT-producing industries was only 3 times as large as the electric motor producing industry in relative terms. The ICT-producing industries also contribute considerably to productivity growth when other countries are investigated and services are included. Moreover, the contribution of the electric motor producing industry to labor productivity growth remains small when hedonic methods are applied.

The results for the technology producing industry indicate that there are important differences in how different GPTs affect productivity growth. The rise in productivity growth due to electricity was the greater flexibility of electric motors. The technological development in the electric motor industry never had a large impact on the whole productivity growth. However, the rapid technological development within the ICTproducing industries themselves has been important for productivity growth during the 
ICT-revolution. Thus, ICT seems to have affected productivity growth both through more flexibility in the production process, but also through rapid innovation in its own technology that have resulted in a larger technology producing sector with higher productivity growth than the electric motor producing industry.

This paper has also shown that the relative contribution of the intensive technology-using industries was considerably higher during electrification. However, the effect is much smaller when the relative size is taken into account. This raises questions whether the method based on the median threshold used by Stiroh (2002) and van Ark (2003) is the best way to separate in which sectors that ICT have had the largest effect. As pointed out by Daveri (2004) setting the arbitrary cut-off point stricter would provide different results. Nevertheless, the results presented here show no evidence that industries that were early adopters of electric motors and ICT, on average would have contributed more to productivity growth. Thus, it is possible to argue that the effects of new technology on productivity growth are dependent on complementary innovations. According to Goldfarb (2005) these co-innovations are often sector specific and appear at different times. This is a possible explanation why there is no indication that early adopters of GPTs to a larger extent contribute more to productivity growth than late adopters.

\section{Appendix}

\section{Appendix A: The revision of Swedish industry classification in 1913}

The revision of the Swedish industry classification in 1913 implied a number of major changes. These are listed below.

1. Mining is included in the official statistics.

2. The following new groups of industrial facilities are included: Dairy, Waterworks and Repair shops for the Swedish state owned railway company. 
3. Only industrial facilities with a) more than 10 persons employed and b) with a production value of more than 10000 SEK or a value added of 3000 SEK are included in the official statistics.

4. Different products produced within the same facility are reported separately.

5. A new classification system is used, where production value is reported at a more aggregated level than before.

6. Production value is reported either as sales value of final products in each industry or the sum of the value of the final products and the intermediary products produced. ${ }^{42}$

\section{Appendix B: Estimation of labor compensation}

Labor compensation has been estimated for the years 1920, 1930 and 1939. The estimates are based on data of wages and the number of individuals employed provided by the Swedish Statistical Yearbook (SSY) (1922-42) and Kommerskollegium (1920-39). According to Kommerskollegium (1920-39), individuals employed can be divided into workers and administrative staff.

The SSY presents wages for workers in each industry. According to the SSY, wages differed widely depending on whether the workers were male, female or individuals aged below $18 .^{43}$ The share of each worker category in total employment is used to weight the wages in each industry. The weighted wages are added to arrive at an average annual wage for each industry. Finally, the average annual wage in each industry is multiplied by the total number of workers employed in that industry. Thus, total labor compensation for workers is estimated for each industry.

\footnotetext{
${ }^{42}$ In this paper, the production value based on the sales values of the final products has been used to avoid double counting to the largest possible extent.

${ }^{43}$ The wage of female workers was only approximately 60 percent of that of male workers throughout the period 1920-39. Moreover, for many industries, wages are only available for male workers. For these industries, it is assumed that the proportional wage difference between male, female and individuals aged below 18 is the same as for total manufacturing.
} 
For administrative staff, there are no wages available for different industries and gender. Instead, SYY presents estimates of different wages for three different categories of administrative staff, namely engineers, clerks and sales clerks. According to Kommerskollegium (1920), there is also another group of administrative staff namely management. Unfortunately, there are no wages available for managers and they are therefore excluded. ${ }^{44}$

Data on the number of engineers, clerks and sales clerks for each industry group are only available for the year 1920. Therefore, the share of engineers, clerks and sales clerks is calculated for each industry in 1920. These shares are then used to weight each of the different wages for engineers, clerks and sales clerks. The shares are then added for each industry and multiplied by the total number of administrative staff in each industry. Since data of engineers, clerks and sales clerks are not available for the years 1930 and 1939, the shares of different administrative staff for these years are based on the shares in 1920. Finally, total labor compensation for workers and administrative staff is added for each industry.

\footnotetext{
${ }^{44}$ By excluding management, it is assumed that managers were paid approximately the same wages in all industries and that the number of managers in each industry is proportional to the number of other employees in that industry.
} 


\section{References}

van Ark, Bart, Inklaar, Robert and McGuckin Robert H. (2003), ”'Changing Gear’ Productivity, ICT and Service Industries: Europe and the United States,” in: Christensen, Jens F. and Maskell, Peter (eds.), The Industrial Dynamics of the New Digital Economy, Edward Elgar, Cheltenham, pp. 56-99.

Van Ark, Bart and Smits, Jan Pieter (2007),” Technology regimes and productivity growth in Europe and the United States - A comparative and historical perspective,” in: Eichengreen, Barry, Stiefle, Dieter and Landesmann, Michael (eds.), The European Economy in American Mirror, Routledge, 2007.

Baily, Martin N. (1986), "Productivity Growth and Material Use in U.S. Manufacturing," Quaterly Journal of Economics, Vol. 101, No. 1, pp. 185-196.

Bresnahan, Timothy F. and Trajtenberg, Manuel (1995), “General Purpose Technologies 'Engines of Growth’?,” Journal of Econometrics, Vol. 65, No. 1, pp. 83-108.

Brynjolfsson, Erik and Hitt, Lorin M. (2000), "Beyond Computation: Information Technology, Organizational Transformation and Business Performance," Journal of Economic Perspectives, Vol. 14, No. 4, pp. 23-48.

Crafts, Nicholas (2004a), "Productivity Growth in the Industrial Revolution: A New Growth Accounting Approach,” Journal of Economic History, Vol. 64, No. 2, pp. 521-535.

Crafts, Nicholas (2004b), "Steam as a General Purpose Technology: A Growth Accounting Perspective," Economic Journal, Vol. 114, No. 495, pp. 338-351.

Daveri, Francesco (2004), “Delayed IT usage: Is it really the drag on Europe’s productivity?,” CESifo Economic Studies, Vol. 50, No. 3, pp. 397-421.

David, Paul A. (1990), "The Dynamo and the Computer: An Historical Perspective on the Modern Productivity Paradox,” American Economic Review, Vol. 80, No. 2, pp. 355-361.

David, Paul A. (1991), "Computer and Dynamo: The Modern Productivity Paradox in a Not-Too-Distant Mirror,” in: Technology and Productivity: The Challenge for Economic Policy, OECD, Paris, pp. 315347.

Devine, Warren (1983), "From Shaft to Wires: Historical Perspective on Electrification," Journal of Economic History, Vol. 43, No. 2, pp. 347-372.

Domar, Evsey (1961), “On the Measurement on Technological Change,” Economic Journal, Vol. 71, No. 284, pp. 709-729.

Du Boff, Richard B. (1979), Electric Power in American Manufacturing 1889-1958, University of Pennsylvania Dissertation (1964), Arno Press, New York.

Edquist, Harald (2005a), “The Swedish ICT Miracle - Myth or Reality?,” Information Economics and Policy, Vol. 17, No. 3, pp. 275-301.

Edquist, Harald (2005b), "Do Hedonic Price Indexes Change History? The Case of Electrification," SSE/EFI Working Paper in Economics and Finance 586, Stockholm School of Economics.

Edquist, Harald and Henrekson, Magnus (2006), “Technological Breakthroughs and Productivity Growth,” Research in Economic History, Vol. 17, No. 3, pp. 275 - 301.

Edvinsson, Rodney (2005), Growth Accumulation Crises - With New Macroeconomic Data for Sweden 1800-2000, Almqvist \& Wiksell, Stockholm.

Field, Alexander J. (2003), “The Most Technologically Progressive Decade of the Century,” American Economic Review, Vol. 93, No. 4, pp. 1399-1413.

Freeman, Christopher and Soete, Luc (eds.) (1987), Technical Change and Full Employment, Basil Blackwell, New York.

Goldfarb, Brent (2005), "Diffusion of general-purpose technologies: understanding patterns in the electrification of the US Manufacturing 1880-1930,” Industrial and Corporate Change, Vol. 14, No. 5, pp. 745-773.

Gordon, Robert J. (2000), “Does the 'New Economy’ Measure up to the Great Inventions of the Past?,” Journal of Economic Perspectives, Vol. 14, No. 4, pp. 49-74.

Gordon, Robert J. (2006), “The 1920s and 1990s in Mutual Reflection,” in: Rhode, Paul and Toniolo, Gianni (eds.), The Global Economy in the 1990s: A Long-Run Perspective, Cambridge University Press, Cambridge, pp. 161-192.

Jalava, Jukka and Pohjola, Matti (2005), “Accounting for $20^{\text {th }}$ Century Finnish Economic Growth: The Roles of Electricity and ICT,” Working Paper, Helsinki School of Economics. 
Jovanovic, Boyan and Rousseau, Peter L. (2005), “General Purpose Technologies,” NBER Working Paper, No. 11093, Cambridge, MA.

Jorgenson, Dale W. and Stiroh, Kevin J. (2000), "Raising the speed limit: U.S. economic growth in the information age,” Brookings Papers on Economic Activity, No. 1, 125-212.

Hjulström, Filip (1940), Sveriges elektrifiering: En ekonomisk-geografisk studie över den elektriska energiförsörjningen, Geographica, No. 8, Uppsala.

Kander, Astrid (2002), Economic growth, energy consumption and $\mathrm{CO}_{2}$ emissions in Sweden, 1800-2000, Almqvist \& Wicksell International, Lund.

Kendrick, John W. (1961), Productivity Trends in the United States, Princeton University Press, Princeton.

KLEMS (2007), EU KLEMS Database, March 2007, http:/www.euklems.net

Kommerskollegium (1906-39), Industri, Stockholm.

Ljungberg, Jonas (1990), Priser och marknadskrafter i Sverige 1885-1969: En prishistorisk studie, Studentlitteratur, Lund.

van Mulligen, Peter H. (2003), Quality Aspects in Price Indices and International Comparisons: Applications of the Hedonic Method, Voorburg, Statistics Netherlands.

Norgren, Lennart (1992), "Svenska verkstäders elektrifiering - Spridningen av elektriska motorer 18961916,” Historisk tidskrift, No. 2, pp. 195-209.

Oliner, Stephen D. and Sichel, Daniel E. (2000), “The Resurgence of Growth in the Late 1990s: Is Information Technology the Story?,” Journal of Economic Perspectives, Vol. 14, No. 4, pp. 3-22.

OECD (2001), OECD Productivity Manual: A Guide to the Measurement of Industry Level and Aggregate Productivity Growth, Directorate for Science, Technology and Industry, Paris.

OECD (2002), “Measuring the Information Economy,” OECD Working Paper, Paris.

Pilat, Dirk and Devlin, Andrew (2004), "The Diffusion of ICT in OECD Economies," in: The Economic Impact of ICT-Measurement, Evidence and Implications, OECD, Paris, pp. 19-36.

Ristuccia, Cristiano and Solomou, Solomos (2002), "Electricity Diffusion and Trend Acceleration in InterWar Manufacturing Productivity, Working paper 0202, University of Cambridge.

Schön, Lennart (1988), Historiska nationalräkenskaper för Sverige: Industri och hantverk 1800-1980, Ekonomisk-Historiska Föreningen, Lund.

Schön, Lennart (1990), Elektricitetens betydelse för svensk industriell utveckling, Vattenfall, Stockholm.

Solow, Robert M. (1987), “We’d Better Watch Out,” New York Times, July 12, p. 36.

Statistics Sweden (2001-2005), Företagens användning av datorer och Internet 2001-2005, Stockholm.

Statistics Sweden (2005), National accounts 1993-2003, Stockholm.

Statistics Sweden (2006), Unpublished data of the ICT capital stock provided by Statistics Sweden, Stockholm.

Stiroh, Kevin J. (2002), ”Information Technology and the U.S. Productivity Revival: What Do the Industry Data Say?,” American Economic Review, Vol. 92, No. 5, pp. 1559-1576.

Swedish Statistical Yearbook (1922-42), Statistisk Årsbok, Kungliga statistiska centralbyrån, Kungliga boktryckeriet P. A. Nordstedt \& Söner, Stockholm.

Triplett, Jack E. (2004), Handbook on Hedonic Indexes and Quality Adjustment in Price Indexes, Directorate for Science, Technology and Industry. OECD, Paris. 